\title{
Modifying Effect of Metallic Powder Fillers
}

\author{
Janusz W. Sikora
}

Katedra Procesów Polimerowych, Wydział Mechaniczny, Politechnika Lubelska, ul. Nadbystrzycka 36, 20-618 Lublin

\begin{abstract}
Industry produces many types and varieties of polymers. Often, however, materials with superior processing and functional properties are needed. Their increased diversity or novel properties can be obtained through chemical and physical modification of polymers, reactive processing or preparation of compositions. The article presents an analysis of mechanical and processing properties of products of polypropylene filled with metallic powder fillers, obtained with constant processing parameters. Samples of polypropylene were subjected to uniaxial stretching by a strength testing machine. Changes in the maximum tensile stress and strain depending on the different content of the metallic filler. Hardness and impact strength of the samples obtained from the injection moulded product were determined and changes in melt flow rate (MFR) were examined. We used five metal powder fillers: aluminium, zinc, tin, iron and copper powders, with their contents ranging from 2.5 to $15 \mathrm{wt} \%$ relative to a polypropylene matrix composite material. Based on the results of research, the appropriate dependencies of different types of powder metal fillers on the mass content were prepared.
\end{abstract}

Keywords: Metal powder filler, polypropylene, mechanical properties, melt flow rate.

\section{Introduction}

The main representatives of polymers from the group of polyolefins are polyethylene, polypropylene and polyisobutylene as well as their copolymers and polymer blends [1]. The development of polyolefin production is related to two important factors: these polymers, whose production cost is relatively low, have a number of valuable functional properties [2] and are also acceptable from the point of view of environmental protection [3]. The polymeric materials from this group are used in the production of packaging, storage tanks, containers, sheets, films, pipes, tubes, household equipment and everyday articles. Polyolefins are easily processed by various methods [4]. Modification of polyolefin materials with various fillers makes it possible to model their physicochemical, mechanical, thermal, electrical, chemical, and processing properties [5].

Constitute an interesting group of materials due to the fact that their properties do not simply result from individual properties of their constituent materials [6], but they also depend on a number of other factors such as the miscibility of their of the constituent materials [7], the type [8], geometry [9] and content of a filler [10], the presence of auxiliary means [11] as well as a plasticizing system design [12] and processing conditions applied, including those of injection moulding and extrusion $[13,14]$. The growing interest in the properties of filled polymers is motivated by their wide and ever-increasing spectrum of applications.

Olefin polymers, in particular polyethylene and poly (vinyl chloride), are very often modified with organic and non-organic fillers. These fillers come in different molecular sizes (nano-, micro- and macro-fillers) and forms (fibres, pellets, plates). Metal powder fillers deserve particular attention here since their effect on the properties of produced composites has not been thoroughly examined 
yet. The advantage of the modification usually consists in considerable improvement in the functional properties of products. On the other hand, the fillers used also cause adverse effects, i.e., increase viscosity and density, and increase moisture absorption of the composition, as well as deteriorate dielectric and processing properties, which also includes increased use of processing equipment.

The primary aim of our study was to determine and estimate the mechanical properties and research of processing of hybrid polypropylene injection mouldings with different contents of powdered metal fillers such as iron, zinc, tin, copper and aluminium powders.

\section{Rationale of the Tooling Fragmentation 2.1 Test stand}

The samples were made using the injection moulding machine DEMAG ERGO tech pro 2580 (max injection pressure 2738 Bar, L/D 24,4, Clamping force $250 \mathrm{kN}$, injection speed $23 \mathrm{ccm} / \mathrm{s}$ ) Figure 1. The test specimens used in experiments for determining the tensile properties of polymer composites were manufactured in the multiple ISO-type form of type A with the Z-type of sprue (samples dimensions according to STN EN ISO 527) - Figure 2. Impact toughness tests were made on test specimens that were injected in the multiple ISO form with dimensions of samples according to STN EN ISO 179-1.

\subsection{Materials}

Composites on the thermoplastic matrix made of polypropylene, with the addition of filler metal powder (iron, zinc, copper and aluminium), were used for the research. The content of the filler metal in the mass fraction varied from $2.5 \%$ to $15.0 \%$ in relation to the matrix. Test specimens were prepared from isotactic polypropylene

Table 1: Physical and chemical properties of metal powder fillers.

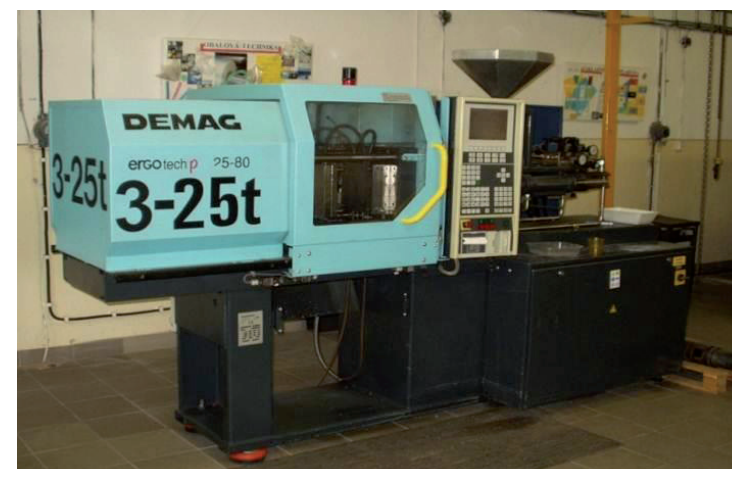

Fig. 1: Injection moulding machine DEMAG ERGO tech pro 25 - 80.

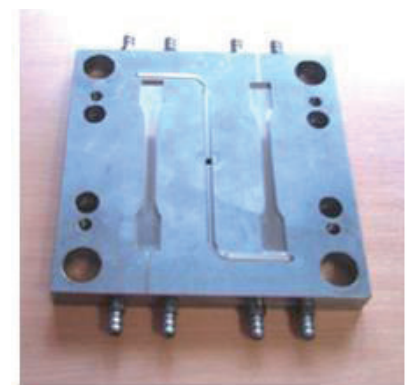

Fig. 2: Experimental multiple ISO-type form of type A for tensile test samples.

homopolymer with the trade name Moplen HP456J, manufactured by Basell Polyolefins. The granulate is intended for injection moulding of products and food contact.

In the experiments, we used five powder metal fillers: copper, iron, aluminium, zinc and tin powders. Their basic properties are listed in Table 1. The fillers were stored in a tightly sealed container and introduced into the plastic immediately prior to processing.

The polymer was filled with each metal powder by mechanical mixing. Simultaneously, we added to the polymer composite an adhesion promoter: $0.4 \%$ carbofunctional silane also known as aminopropyltriethoxysilane [15], to modify the surface of the inactive polypropylene.

\begin{tabular}{|l|l|l|l|l|l|l|}
\hline Properties & \multicolumn{5}{c}{ Filler } \\
\hline Standard density, $\mathrm{kg} / \mathrm{m}^{3}$ & \multicolumn{1}{c|}{ Copper } & \multicolumn{1}{c|}{ Iron } & \multicolumn{1}{c|}{ Aluminium Zinc } \\
\hline Bulk density, $\mathrm{kg} / \mathrm{m}^{3}$ & 8960 & 7860 & 2700 & 6900 & 3600 \\
\hline Grain size, $\mu \mathrm{m}$ & 1600 & 2800 & 1200 & 3600 & 1180 \\
\hline Form & $45-106$ & 150 & $45-100$ & $30-40$ & 45 \\
\hline Melting point ${ }^{\circ} \mathrm{C}$ & & 1080 & 1535 & 660 & 409 & 232 \\
\hline
\end{tabular}




\subsection{Experimental procedure}

The first stage of research was to prepare a mixture of polypropylene with filler in an appropriate ratio. An appropriate mass fraction of the metal filler, with the addition of an adhesion promoter, was added to $550 \mathrm{~g}$ of the base material. The resulting mixture was introduced into a tank, starting the injection of a composite. 10 cycles of injection moulding process were performed, during which the mouldings were discarded. Subsequent products constituted test samples. When the plasticizing system of the injection moulding machine was emptied, another portion of the prepared mixture was introduced to its tank - with another mass fraction of the filler. After completion of all samples with one filler, some mixtures of polypropylene with another filler were prepared and the steps were repeated.

The static tensile tests were conducted in compliance with ISO 527-1:1998 [16]. The hardness tests were performed according to the procedures laid down in ISO 868:2005 [17] while the impact strength tests were run in compliance with ISO 179-2:1997 [18]. Determination of the process ability of thermoplastics with a melt flow rate was carried out in accordance with the guidelines in ISO 1133-1:2011 [19].

\section{Experimental results and discussion}

Theresults oftests presented in theworkconstitute a summary of data selected from all measurements and are average values determined on the basis of multiple repetitions of measurements carried out in the same conditions. Figures 1-5 present dependencies of the mechanical and processing properties of the hybrid injection mouldings on a different content of the powder filler metal.

\subsection{Strength tests of the moulded products}

The polypropylene filled with iron, zinc, copper and aluminium powders exhibits a lower ultimate tensile stress (Fig. 3) in the entire range of the tested metal filler contents. When the polymer is filled with $2.5 \%$ tin powder, its tensile stress increases by $4.88 \%$; however, when the $\mathrm{Sn}$ content is higher, it causes a decrease in the ultimate tensile stress of the composite. The addition of the aluminium metal filler makes the ultimate tensile stress decrease the most: this parameter decreases by $11.58 \%$ in the entire range of the tested Al filler content. This behaviour can probably be attributed to the fact that we reached the filler content reached the level when filler agglomerates begin to form in the material [20]. The presence of such inclusions increases the effect of a mechanical notch and causes reduction of the section of the polymer subjected to stresses [8].

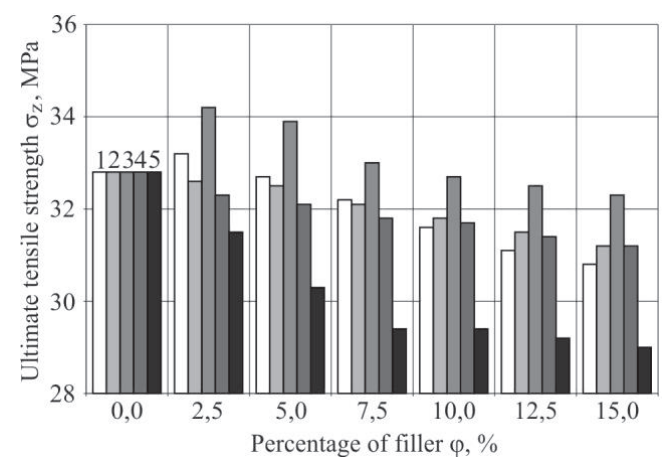

Fig. 3: Ultimate tensile stress $\sigma_{\mathrm{z}}$ versus the content $\varphi$ of different metal powder fillers: 1 - Fe, $2-C u, 3-S n, 4-Z n, 5-A l$.

The strain $\varepsilon_{\mathrm{z}}$ at maximum tensile stress (Fig. 4) decreases regardless of the type of the metal powder filler applied. For iron, tin and aluminium fillers, this decrease is relatively gentle in the entire range of powder filler contents. For copper and zinc fillers, however, the following trend can be observed: at smaller $\mathrm{Cu}$ and $\mathrm{Zn}$ contents (up to 10\%) the strain $\varepsilon_{\mathrm{z}}$ at ultimate tensile stress gently decreases only to drop rapidly at higher $\mathrm{Cu}$ and $\mathrm{Zn}$ contents.

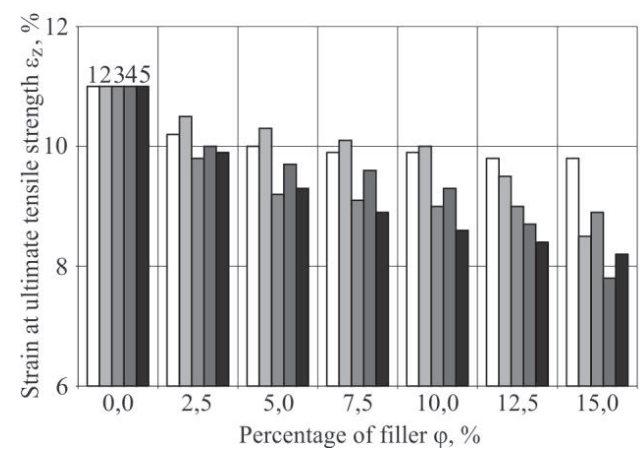

Fig. 4: Strain $\varepsilon_{\mathrm{z}}$ at ultimate tensile stress versus the content $\varphi$ of different metal powder fillers: 1 - Fe, 2-Cu, 3-Sn, 4-Zn, 5-Al.

Within the entire range of different filler contents, the smallest decrease in the strain $\varepsilon_{\mathrm{z}}$ at ultimate tensile stress (by 10.9\%) can be observed for the iron filler, whereas the highest decrease in the 
strain $\varepsilon_{z}$ at ultimate tensile stress is exhibited by the zinc- and aluminium-filled polymer composite, by $29.1 \%$ and $25.45 \%$, respectively. The lower strain at ultimate tensile stress of the filled moulded products compared to the unfilled polypropylene composite can result from incorrect adhesion of metal particles to the polymer matrix [7].

\subsection{Hardness of hybrid moulded products}

In order to determine the effect of metal powder filler contents on the hardness of hybrid moulded products, we conducted Shore D hardness tests. The results are given in Fig. 5 as the relationships between hardness measured by the Shore D scale and different contents of the tested metal powder fillers.

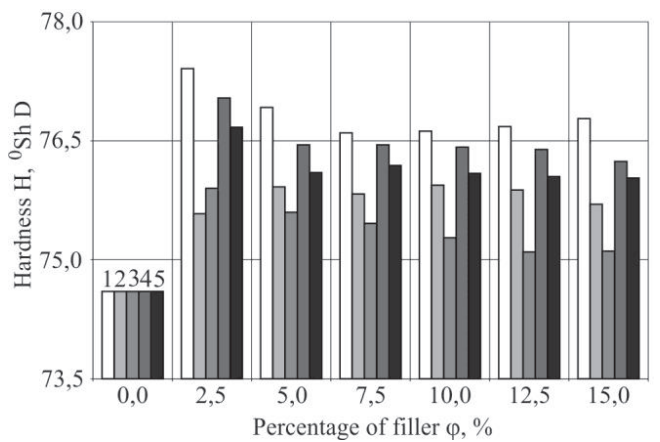

Fig. 5: Hardness $\mathrm{H}$ of hybrid moulded products determined by the Shore method versus the content $\varphi$ of different metal powder fillers: $1-F e, 2-C u, 3-S n, 4-Z n, 5-A l$.

The hardness of the tested hybrid moulded products increases with increasing the powder filler content irrespective of a filler type applied. After that, the hardness decreases and then remains stable, its magnitude being higher than that of the unfilled polypropylene. The highest hardness can be observed for moulded products filled with $2.5 \%$ iron, zinc, tin and aluminium powders and with 5\% copper powder. The hardness value is the highest at $2.5 \%$ filler content for iron powder and it amounts to $3.77 \%$, which means that the hardness increased by $2.8 \mathrm{oShD}$. Then it decreases by approx. $1 \%$. Given the above, it can be concluded that the optimum content of metal fillers such as iron, tin, zinc and aluminium is approx. 2.5\%; with copper filler, however, the optimum content is higher and should be set to $5 \%$. The effect of a higher filler content is the production of filler agglomerates in the composite, which - combined with the filler's poor adhesion to the polymer matrix - results in a decreased hardness of the moulded products [21].

\section{$\mathbf{3 . 3}$ Impact strength tests}

The results of the conducted Charpy impact strength tests of hybrid moulded products are given in Figure 6 as the relationships between impact strength and different contents of the tested fillers.

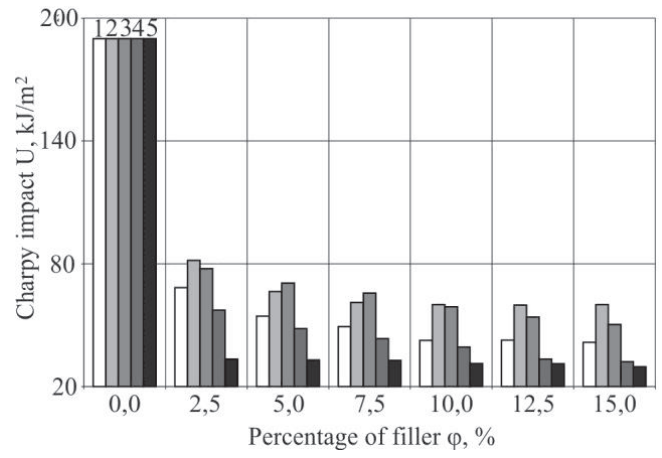

Fig. 6: Charpy impact strength $U$ of hybrid composites versus the content $\varphi$ of different metal powder fillers: $1-F e, 2-C u, 3-S n$, $4-Z n, 5-A l$.

Metal powder-filled polypropylene composites exhibit a sharp decrease in their impact strength regardless of filler contents applied. The highest decrease in impact strength can be observed for the Al filler, while the lowest one is exhibited by the copper-filled polypropylene composites. At $2.5 \% \mathrm{Cu}$ content, the impact strength of moulded products decreases by almost 60\%, while the addition of the same content of aluminium powder decreases the impact strength by over $81 \%$. Filling polypropylene with higher contents of the tested metal powder fillers does not affect the impact strength of the produced composites to such a significant extent. Increasing the filler content from $2.5 \%$ to $15.0 \%$, i.e. by $500 \%$, leads to a decrease in the impact strength by several percent. This can point to the occurrence of re-crystallization and crystallite increase in the moulded products, which produces a coarse-grained structure and a higher degree of crystallinity. The higher the filler content is in the polymer, the more brittle the polymer is [22].

\subsection{Impact strength tests}

The test results for the melt flow rate of hybrid injection mouldings with different amounts of filler metal powder are presented in the figure 7 , in the 
form of appropriate graphic dependence.

An addition of filler metal powders in the amount of $2.5 \%$ to the polypropylene powder, regardless of its type, results in a rapid decrease of the melt flow rate of hybrid mouldings. The largest decrease for aluminium, the smallest one for zinc. The addition of aluminium powder in the amount of $2.5 \%$ results in a decrease of MFR by over 36\%, which corresponds to a decrease of the value of $1.24 \mathrm{~g} / 10$ min, and then there is an increase of approx. $3 \%$. An addition of the same amount of tin powder results in a decrease of the process ability ratio by $28 \%$. Adding more amounts of the tested fillers results in a slightly smaller decrease of the selected feature, followed by its stabilization at a certain level - lower than for pure polypropylene. The largest value of the melt flow rate can be noted in the case of zinc and amounts to $2.7 \mathrm{~g} / 10 \mathrm{~min}$. The melt flow rate is a value that combines the general characteristics of the chemical and physical properties of a given material $[23,24]$. A low melt flow rate indicates a low viscosity of the material under certain conditions, which in turn may be caused by strongly branched macromolecular structure [25]. With increasing percentage of the filler metal, the viscosity of the tested material in the plasticized state also increases, as can be seen in the graphs presenting the dependency of the melt flow rate on the filler content. Introducing to the base material of a filler of much higher density also increases the density of the filled material.

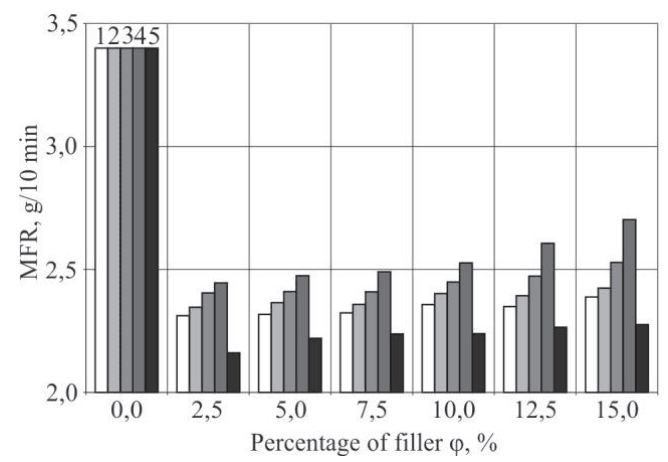

Fig. 6: Dependence of the melt flow rate of hybrid composites versus the content $\varphi$ of different metal powder fillers: $1-\mathrm{Fe}, 2-\mathrm{Cu}$, $3-S n, 4-Z n, 5-A l$.

\section{Conclusions}

The results of the tensile strength demonstrate that the maximum tensile stresses decrease.
Nonetheless, the results show that the filled polypropylene has a relatively high strength and can, thus, be used as a constructional polymer material.

The hybrid moulded products with different metal powder filler contents have an increased hardness compared to that of the unfilled polymer. The highest hardness value was observed for the specimens with $2.5 \%$ filler content in the polymer, whereas any further increase in the filler content beyond this value led to a significant decrease in the hardness of the tested specimens.

In addition, the experimental results demonstrate that the filler content has a significant effect on the impact strength of the produced polymer composites - on increasing the filler content, the impact strength of the moulded products sharply decreased.

In the case of MFR test, a definite deterioration of processing properties of the prepared polymer compositions was stated, throughout the tested range of the filler mass content, noting a rapid decline in the process ability index with a low proportion of metal powder in the plastic polymer.

\section{Acknowledgments}

We wish to express our deep sense of gratitude to the Slovak Academic Information Agency for enabling us to conduct the research at the Technical University of Kosice under the National Scholarship Programme of the Slovak Republic.

\section{References}

[1] Szlezyngier W., Brzozowski Z. K.: "Tworzywa sztuczne. Tom 1. Tworzywa ogólnego zastosowania". Rzeszów 2012.

[2] Kuciel S., Kuźniar P.: „Materiały polimerowe”, Politechnika Krakowska, Kraków 2013.

[3] Szlezyngier W.: "Tworzywa sztuczne. Chemia. Technologia wytwarzania. Właściwości. Przetwórstwo. Zastosowanie". Oficyna Wydawnicza Politechniki Rzeszowskiej, Rzeszów 1996.

[4] Sikora R.: "Przetwórstwo tworzyw wielkocząsteczkowych". Wydawnictwo Edukacyjne, Warszawa 1993.

[5] Gościański M., Maciejewski H., Guliński J., Leda H.: „Badanie wpływu modyfikacji mineralnych napełniaczy proszkowych silanami na wybrane właściwości mechaniczne liniowego polietylenu małej gęstości", Polimery 2004, 49, 1, 15-23

[6] Sikora R.: „Przetwórstwo tworzyw polimerowych. Podstawy logiczne formalne i terminologiczne". Politechnika Lubelska: Lublin, 2006.

[7] Chiang W.-Y., Yang W.-D, Pukánszky B.: "Polypropylene com- 
posites. II: Structure-property relationships in two- and three-component polypropylene composites". Polymer Engineering \& Science 1992, 32, 10, 641-648.

[8] Rusu M., Dãrângã M., Sofian N. M., Rusu D. L.: "Polymer composite materials with metal fillers". Materiale Plastice 1998, $35,1,15-21$

[9] Garbacz T.: "Structure and properties of cellular injection molded products". Polimery 2013, 58, 4, 30-38.

[10] Amash A, Zugenmaier P.: "Thermal and dynamic mechanical investigations on fiber-reinforced polypropylene composites". Journal of Applied Polymer Science 1997, 63, 9, 1143-1154.

[11] Sikora J., Samujło B., Stasiek A.: "The extrusion of plasticized poly(vinyl chloride) in an extruder with a modified feed zone. Part 1: extrusion process". Journal of Polymer Engineering 2014, 34, 1, 77-85

[12] Sikora J., Duleba B., Dulebova L., Greškovič F.: "Evaluation of process wear of selected tool steels for injection molds". Advanced Materials Research 2013,739, 171-176.

[13] Garbacz T.: „Struktura i właściwości porowatych wytworów wtryskiwanych". Polimery 2013, 58, 4, 295-303.

[14] Klepka T, Dębski H, Rydarkowski H.: "Characteristics of highdensity polyethylene and its properties simulation with use of finite element method". Polimery 2009, 54, 9, 668-673.

[15] Jachowicz T., Gajdoš I., Krasinskyi V.: "Research on the content and filler type on injection shrinkage". Advances in Science and Technology Research Journal 2014, 23, 8, 6-13.

[16] ISO 868:2005. Plastics and ebonite - Determination of indentation hardness by mean of a durometer (Shore hardness).

[17] ISO 527-1:1998. Plastics - Determination of tensile properties - Part 1: General principles.

[18] ISO 179 - 2: 1997. Plastics - Determination of Charpy impact properties - Part 2: Instrumented impact test.

[19] ISO 1133-1:2011. Plastics - Determination of the melt massflow rate (MFR) and melt volume-flow rate (MVR) of thermoplastics - Part 1: Standard method

[20] Taşdemir M.; Ozkan Gülsoy H.: "Mechanical Properties of Polymers Filled with Iron Powder". International Journal of Polymeric Materials and Polymeric Biomaterials 2008, 57, 3, 189-293.

[21] Bishay K., Abd-El-Messieh S.L., Mansour S. H.: "Electrical, mechanical and thermal properties of polyvinyl chloride composites filled with aluminum powder". Materials \& Design 2011, 32, 1, $62-68$.

[22] Gungar A.: "Mechanical properties of iron powder filled high density polyethylene composites". Materials \& Design 2007, 28, 3, $1027-1030$.

[23] Liang J. Z.: "The elastic behaviour during capillary extrusion of LDPE/LLDPE blend melts". Polymer Testing 2002, 21, 69-
74

[24] Wong A. C.-Y., Liang J. Z.: "Relationship between die swell ratio and melt flow index". Chemical Engineering Science 1997, 52, 18, 3219-3221

[25] Floriańczyk Z., Penczek S. (pod red.): „Chemia polimerów. T. 2". Oficyna Wydawnicza Politechniki Warszawskiej, Warszawa 2002. 